\title{
Hydrothermal uranium-base metal mineralization of the Jánská vein, Březové Hory, Př́bram, Czech Republic: lead isotopes and chemical dating of uraninite
}

\author{
Pavel ŠKÁCHA ${ }^{1 *}$, Viktor GOLIÁŠ ${ }^{1}$, Jiří SEJKORA², Jakub PLÁŠIL'1,2, Ladislav STRNAD², Radek \\ ŠKODA ${ }^{4}$, Josef JEŽEK ${ }^{5}$ \\ ${ }^{1}$ Institute of Geochemistry, Mineralogy and Mineral Resources, Charles University in Prague, Faculty of Science, Albertov 6 , \\ 12843 Prague 2, Czech Republic; skachap@volny.cz \\ 2 Department of Mineralogy and Petrology, National Museum, Václavské nám. 68, 11579 Prague 1, Czech Republic \\ ${ }^{3}$ Laboratories of Geological Institutes, Charles University in Prague, Faculty of Science, Albertov 6, 12843 Prague 2, Czech Republic \\ ${ }^{4}$ Institute of Earth Sciences, Faculty of Science, Masaryk University, Kotlářská 2, 61137 Brno, Czech Republic \\ ${ }^{5}$ Institute of Applied Mathematics and Information Technologies, Charles University in Prague, Faculty of Science, Albertov 6 , \\ 12843 Prague 2, Czech Republic \\ * Corresponding author
}

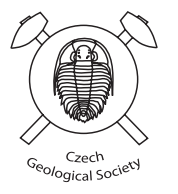

The Jánská vein is one of the important veins of Březové Hory mining district (central Bohemia, Czech Republic). Base metals were mined here since $14^{\text {th }}$ century and uranium ore during late 1950 's.

Uranium mineralization is younger than most of the base metal mineralization according to macroscopic and microscopic study. Most specimens of uraninite, obtained from archive, contain more or less abundant galena inclusions. Galena of this type is non-radiogenic as indicated by its $\mathrm{Pb}$ isotopic composition (ICP-MS). Its origin can be explained by remobilisation of the older base-metal mineralization during the younger, uranium-bearing mineralization event. The amount of radiogenic $\mathrm{Pb}$ in uraninite fluctuates from 48 up to $89.8 \%$. The age of theoretical end member of uraninite, calculated statistically from all measured data (for intersection ${ }^{208} \mathrm{~Pb} /{ }^{206} \mathrm{~Pb}=0$ ), is $269.8 \pm 20.3 \mathrm{Ma}(2 \sigma)$. The only uraninite grain without galena inclusions yielded an age of $263.2 \pm 8.9$ Ma by chemical dating using electron microprobe. The calculated age of the uranium mineralization is in agreement with published data for other uranium deposits genetically associated with the Central Bohemian Plutonic Complex.

Keywords: uranium, Přibram-Březové Hory, Jánská vein, lead isotopes

Received: 26 March 2008; accepted 14 May 2008; handling editor: E. Jelinek

\section{Introduction}

The Prríbram ore region (central Bohemia, Czech Republic) consists of two ore districts, namely Př́bram uranium-base metal district and the Březové Hory base metal district. This ore field is the most important $\mathrm{Ag}-$ $\mathrm{Pb}-\mathrm{Zn}-\mathrm{U}$ accumulation in the Bohemian Massif mined to date having produced in total more than $500,000 \mathrm{t}$ of lead, 3,500 t of silver and 43,000 t of uranium. The mining reached depths of $1,500 \mathrm{~m}$ in the Březové Hory ore district (Prokop shaft) and $1,850 \mathrm{~m}$ in the Uranium district (shaft № 16). General characteristics of the base metal deposit were summarized by Bambas (1990) and description of uranium deposit was given in Arapov et al. (1984). The uranium mineralization manifestations were relatively rare in the Březové Hory ore district, having been concentrated in several veins only. One of the veins, where uranium mineralization was relatively abundant, is the Jánská vein. It is localized in the centre of the Březové Hory deposit, in the most productive part of the Březové Hory ore district. The ages of ura- nium mineralization in Př́bram ore field available to date are related only to the Uranium district. The main goal of this article is the presentation of new data on the isotopic composition of lead in galena and uraninite, as well as their bearing on dating of the primary mineralization in the Březové Hory ore district.

\section{Geological setting}

\subsection{General characteristics of the Březové Hory ore district}

The Březové Hory district and the Uranium district are spatially related to the exocontact of the Central Bohemian Plutonic Complex (CBPC), which was dated to 338-354 Ma (for literature related to $\mathrm{U} / \mathrm{Pb}$ zircon dating of CBPC see Holub et al. 1997 and Janoušek et al. 2004). The ${ }^{40} \mathrm{Ar}-{ }^{39} \mathrm{Ar}$ cooling ages (338-352 Ma) of different plutonic and dyke rocks from the Príbram area (Vrančice, Lešetice and Bohutín) suggest a close temporal relation 


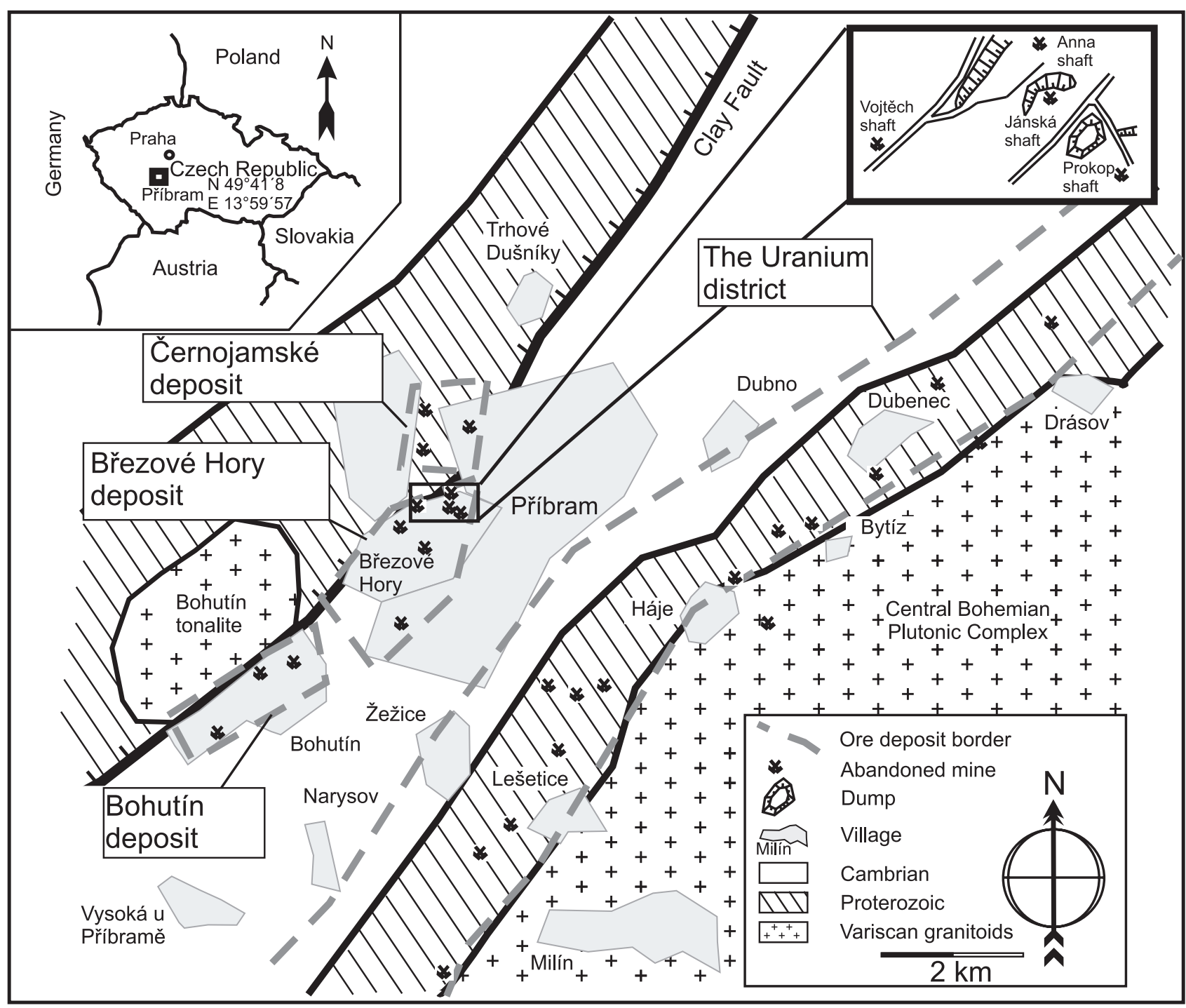

Fig. 1 Generalized geological setting of the Prríbram base metal and uranium districts. Shown are outlines of individual ore deposits as well as the position of mines (including the Jánská shaft).

between magmatism of the CBPC and the early stages of the base-metal mineralization (Žák et al. 1998).

The Březové Hory ore district can be subdivided into three deposits: central Březové Hory, Černojamské, and Bohutín (Fig. 1). The age of beginning of the Březové Hory ore district exploitation is unknown. Mining at the outcrops of the veins is documented by archaeological study to the $13^{\text {th }}$ century. The exploitation was very intense in the whole deposit in the $16^{\text {th }}$ century (Grimm 1856). The attention was focused again on the central part of mining district in the $18^{\text {th }}$ century, especially for the Jánská vein. The whole Březové Hory ore district was intensively mined during the $19^{\text {th }}$ century and the prosperity period finished at the end of the same century. Mining was unprofitable during most of the $20^{\text {th }}$ century and it was terminated in 1979.
The hydrothermal veins of the Březové Hory penetrated Neoproterozoic and Cambrian volcanosedimentary formations. The Cambrian sequence includes greywackes, sandstones and conglomerates. The sedimentary rocks were intruded by a swarm of dolerite ("diabase") dykes up to several tens of metres wide. Ore veins are often preferentially localized along these dolerite dykes.

According to relative age of formation, the mineralization is divided into an Early Variscan gold-bearing quartz period and a Late Variscan base metal period (Bambas 1990; Zachariáš and Stein 2001). The two periods are separated by an interval of c. $100 \mathrm{Ma}$, but they often follow the same structures. The Early Variscan mineralization, which is important for the Bohutín deposit, was not observed in the Jánská vein. The Late Variscan mineralization was a single polyascendent mineralization 
process of Early or Late Permian age. The average U$\mathrm{Pb}$ isotope age of uraninites from the adjacent Uranium district, belonging to this mineralization, is $265 \pm 15 \mathrm{Ma}$ (Legierski 1973) or $275 \pm 4 \mathrm{Ma}$ to $278 \pm 4 \mathrm{Ma}$ (Anderson 1987). Direct dating of the mineralization in the Březové Hory ore district is so far missing.

According to the stable isotope and fluid inclusions studies, the formation temperatures of the Březové Hory ore district veins generally range from 150 to $300{ }^{\circ} \mathrm{C}$. Fluids were high-saline (15-25 wt. \% $\mathrm{NaCl}$ eq.) and their oxygen was isotopically heavy $\left(\delta^{18} \mathrm{O}=+6\right.$ to $+10 \%$ SMOW). On the other hand, temperatures of formation for the nearby Uranium district were lower $\left(80-130{ }^{\circ} \mathrm{C}\right)$ and characterized by low salinity $(\max 5 \mathrm{wt} . \% \mathrm{NaCl}$ eq.) with $\delta^{18} \mathrm{O}$ ranging between -4 and $+6 \%$ SMOW (Žák and Dobeš 1991). This probably points to a distinct source of the $\mathrm{U}$ mineralization.

\subsection{Description of the filling and geologic conditions of the Jánská vein}

The Jánská vein is located in Cambrian rocks between the Anna and Vojtěch shafts in the central Březové Hory ore deposit. It is one of smaller range veins (it was observed over a maximal length of about $200 \mathrm{~m}$ ) in a relatively dense and involved veins system seen at the surface. The Janská vein was opened by mining works from surface down to the $18^{\text {th }}$ level; however it gradually wedges-out at deeper levels, loosing its economic importance. In the northwest its trend is $330^{\circ}$ and it gradually swings to $350^{\circ}$ behind its crossing with the Václav vein. The dip is relatively stable at $60-70^{\circ}$ to the northeast.

The structure of the Jánská vein can be described as banded and asymmetric in most cases, less commonly brecciated. The mineral assemblage does not differ significantly from that of other veins in the Březové Hory ore district. Its structure can be described as banded and asymmetric in most cases, less commonly brecciated. It was observed over a maximal length of $c$. $200 \mathrm{~m}$. The vein was mined between the $1^{\text {st }}$ and $18^{\text {th }}$ levels, where it lost its thickness and economic ore content. Filling contains quartz, barite and carbonates. Main ore minerals are represented by galena, sphalerite, silver ores, pyrite and uraninite (Fig. 2). According to Babánek (1870), the Jánská vein belongs to the youngest group of veins in the Březové Hory deposit. Its apophyses were rich in silver minerals at the $17^{\text {th }}$ level, especially close to the Clay Fault. The host rocks are often hydrothermally altered, rock bleaching and a distinct haematitization is evident in the southern parts of the vein at the $1^{\text {st }}$ and $2^{\text {nd }}$ levels. A report by Author Collective (1949) described plagioclase pinitization, epidotization and sericitization in wall rock next to the vein. The Jánská vein's width varies much from 1 to $20 \mathrm{~cm}$; in places it even passes to a non-mineralized dislocation.

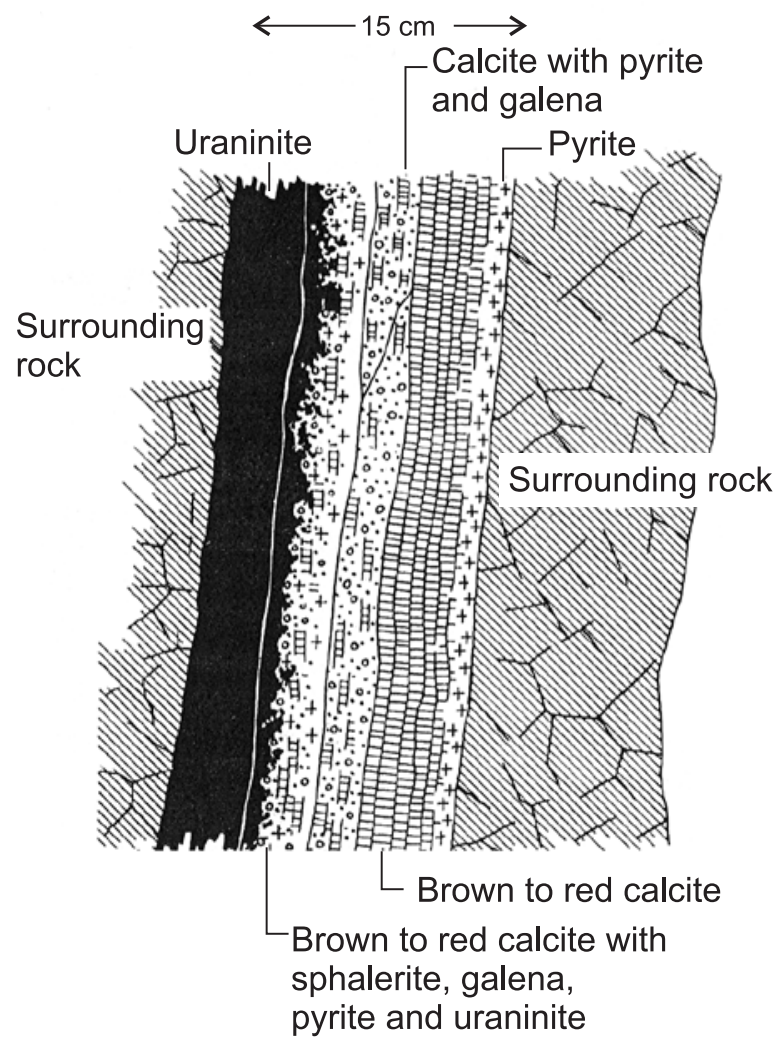

Fig. 2 Sketch of the ore fill in the Jánská vein (Schmidt 1892 modified by Kirchheimer 1963).

According to Schmidt (1892), uraninite was found from surface down to the $12^{\text {th }}$ level, where the Jánská vein and Jánská upper vein meet. At this place uraninite was richly intergrown with pyrargyrite or proustite. At the $16^{\text {th }}$ level, where the Jánská upper vein branched out, uraninite was absent.

\section{Methods}

The X-ray powder diffraction analysis was used for phase analysis. To minimize complicated shape of background due to classic glass sample holder, the samples studied were placed on the surface of flat silicon wafer mostly in alcoholic suspension. Continuous mode of PANalytical $\mathrm{X}^{\prime}$ Pert Pro diffractometer with $\mathrm{X}^{\prime}$ Celerator detector was used for collecting powder diffraction data. It was operated at $40 \mathrm{kV}$ and $30 \mathrm{~mA}$, and secondary monochromator producing CuK $\alpha 1,2$ radiation was used (X-ray Diffraction Laboratory at Institute of Geochemistry, Mineralogy and Mineral Resources, Faculty of Science, Charles University in Prague). Phase analysis was done using the search-match algorithm of High-Score program with PDF-2 database (ICDD 2003). 
Chemical composition of galena was analysed using Cameca SX100 electron microprobe (State Geological Institute of Dionýz Štúr, Bratislava). The analyses were performed at $20 \mathrm{kV}$ and $20 \mathrm{nA}$ using $c .1 \mu \mathrm{m}$ beam diameter; counting times were 30-60 s. The following standards were used during the analysis: $\mathrm{Ag}(\mathrm{Ag})$; $\mathrm{Cd}(\mathrm{Cd})$, As (FeAsS), $\mathrm{Sb}\left(\mathrm{Sb}_{2} \mathrm{~S}_{3}\right)$; $\mathrm{Te}\left(\mathrm{Bi}_{2} \mathrm{Te}_{3}\right)$; $\mathrm{Cu}, \mathrm{Fe}, \mathrm{S}\left(\mathrm{CuFeS}_{2}\right)$; $\mathrm{Cl}(\mathrm{NaCl}) ; \mathrm{Pb}(\mathrm{PbS}) ; \mathrm{Bi}(\mathrm{Bi}), \mathrm{Hg}(\mathrm{HgS})$ and $\mathrm{Cl}(\mathrm{NaCl})$.

Chemical composition of uraninite was studied by Cameca SX100 electron microprobe (Joint Laboratory of Electron Microscopy and Microanalysis of the Masaryk University and Czech Geological Survey in Brno). The operating conditions were as follows: an accelerating voltage $15 \mathrm{kV}$, a beam current of $80 \mathrm{nA}$ and a beam diameter of $2 \mu \mathrm{m}$. Peak counting times were $40-60 \mathrm{~s}$ for most minor elements. Uranium was determined on the $\mathrm{U} M \beta$ line (detection limit $270 \mathrm{ppm}$ ), thorium on the Th $M \alpha$ line (detection limit $250 \mathrm{ppm}$ ) and $\mathrm{Pb}$ on the $\mathrm{Pb}$ $M \alpha$ line (detection limit $130 \mathrm{ppm}$ ). The following standards were used: $\mathrm{U}-$ metallic $\mathrm{U}, \mathrm{Pb}-\mathrm{PbSe}, \mathrm{Th}-\mathrm{ThO}_{2}$, $\mathrm{P}, \mathrm{F}$ - fluorapatite, $\mathrm{Y}-\mathrm{YAG}, \mathrm{La}-\mathrm{LaB}_{6}, \mathrm{Ce}-\mathrm{CeAl}_{2}$, $\mathrm{Pr}-\mathrm{PrF}_{3}, \mathrm{Nd}-\mathrm{NdF}_{3}, \mathrm{Sm}-\mathrm{SmF}_{3}, \mathrm{Gd}-\mathrm{GdF}_{3}$, Dy - $\mathrm{DyP}_{5} \mathrm{O}_{14}, \mathrm{Er}-\mathrm{YErAG}, \mathrm{Yb}-\mathrm{YbP}_{5} \mathrm{O}_{14}, \mathrm{Al}$ - almandine, $\mathrm{Si}, \mathrm{Ca}, \mathrm{Fe}$ - andradite, $\mathrm{Mn}$ - rhodonite, $\mathrm{V}$ - vanadinite, $\mathrm{S}-$ barite. Data were reduced using the PAP matrix correction routine (Pouchou and Pichoir 1985).

Assuming that the total $\mathrm{Pb}$ in uraninite is only radiogenic, i.e. resulting by decay of $\mathrm{Th}$ and $\mathrm{U}$, the chemical age can be calculated using the equation close to published by Montel et al. 1996:

$$
\begin{aligned}
& \mathrm{Pb}=\frac{\mathrm{U}}{238.03} \times 0.99276 \times\left(\mathrm{e}^{\lambda_{238}}-1\right) \times 205.97+\frac{\mathrm{U}}{238.04} \\
& \times 0.007196 \times\left(\mathrm{e}^{\lambda_{235^{\mathrm{t}}}}-1\right) \times 206.98+\frac{\mathrm{Th}}{232.04} \times 0.99276 \times \\
& \left(\mathrm{e}^{\lambda_{232^{\mathrm{t}}}}-1\right) \times 207.97,
\end{aligned}
$$

where $\lambda^{238}, \lambda^{235}$, and $\lambda^{232}$ are decay constants of the ${ }^{238} U$, ${ }^{235} \mathrm{U}$ and ${ }^{232} \mathrm{Th}$, respectively. Additionally, the concentrations of $\mathrm{Pb}$ were manually corrected for $\mathrm{Y} \mathrm{L} \gamma_{2}, \mathrm{Th} \mathrm{M} \zeta_{1}$ and $\mathrm{Th} \mathrm{M} \zeta_{2}$ overlaps on PbM $\alpha$. Besides the mentioned coincidences, the analytical precision of $\mathrm{Pb}$ on the $\mathrm{M} \alpha$ line is higher than on $\mathrm{M} \beta$ line, where only insignificant coincidences occur. Lower analytical totals for uraninite analyses are primarily caused by its porous nature or by a higher oxidation state of uranium $\left(\mathrm{U}^{\mathrm{VI}+}\right)$.

The isotopic data were obtained by ICP-MS (Laboratories of Geological Institutes, Charles University in Prague). The procedure used for the geological samples decomposition was similar to Strnad et al. (2005). The only non-radiogenic $\mathrm{Pb}$ isotope is ${ }^{204} \mathrm{~Pb}$, which is normally used as denominator for reporting isotopic $\mathrm{Pb}$ ratios (Faure 1986). This isotope shows a low abundance (c. $4 \%$ ) and radiogenic systems contain even less of this isotope. Low sensitivity and accuracy for determination of isotopic ratios involving ${ }^{204} \mathrm{~Pb}$ was the reason, why it was replaced by ${ }^{208} \mathrm{~Pb}$, originating by $\mathrm{Th}$ decay. It can be treated as an essentially „non-radiogenic“ isotope because the studied hydrothermal uraninite does not contain any appreciable amounts of Th. This was confirmed by our chemical analyses (EMPA) and by alpha spectroscopy (Jarka 2007). Thorium, unlike uranium, occurs only in tetravalent state and under oxidation conditions (at hydrothermal stage) both elements fractionate from each other.

The ${ }^{207} \mathrm{~Pb} /{ }^{206} \mathrm{~Pb}$ and ${ }^{208} \mathrm{~Pb} /{ }^{206} \mathrm{~Pb}$ isotopic compositions were determined using a standard configuration of quadrupole-based ICP-MS PQ3 (VG Elemental, UK) equipped with a water-cooled $\left(\sim 4{ }^{\circ} \mathrm{C}\right)$ spray chamber with Meinhard-type nebuliser. The analytical conditions and data acquisition parameters closely followed those described in Mihaljevič et al. (2006). The data were acquired in the peak-jumping mode with 4 points measured per mass peak and instrument sensitivity at $3 \times 10^{4} \mathrm{cps}$ per $1 \mathrm{ng} \cdot \mathrm{ml}^{-1}$ ${ }^{209} \mathrm{Bi}$. The total acquisition time was $10 \times 30 \mathrm{~s}$. Correction for the mass bias was performed using NIST SRM 981 (a common lead isotopic standard) and SRM 982 (an equal atom lead isotopic standard) after every analysed sample and the time-resolved data were processed off line in a MS Excel program. The standard errors for measurements of the ${ }^{207} \mathrm{~Pb} /{ }^{206} \mathrm{~Pb}$ and ${ }^{208} \mathrm{~Pb} /{ }^{206} \mathrm{~Pb}$ ratios were below $0.5 \%$ (relative). The accuracy of the measurements was controlled by repeated analysis of the AGV-2 standard (USGS, USA; ${ }^{207} \mathrm{~Pb} /{ }^{206} \mathrm{~Pb}=1.2085 \pm 0.0006,{ }^{208} \mathrm{~Pb} /{ }^{206} \mathrm{~Pb}$ $=2.0415 \pm 0.0013$ ). Software NCSS (Hintze 2001) was used for statistical treatment of the isotopic data.

\section{Mineralogy and geochemistry of the ores}

\subsection{Ore distribution in the Jánská vein}

From the results of field study, examination of an old mining map from 1760 (private collection) and archive documents of the uranium survey from the period 19481949 (Author Collective 1949) follows that the uranium mineralization is concentrated in two ore pillars.

The northern ore pillar, which is located near the Jánská shaft, is vertical, splays out to the depth and its position is probably controlled by the Václav vein and the Clay Fault.

The southern ore pillar, localized in the southeastern part of the Jánská vein, where mining was concentrated during the period 1948-1949, was dipping c. $35^{\circ}$ to the southeast (in a vertical projection of the Jánská vein). Joint occurrence of uranium and copper mineralization without occurrences of macroscopic galena (in the area of $1^{\text {st }}$ and $2^{\text {nd }} l e v e l$ ) is typical. Longitudinal projection following the Jánská vein down to the level of $12^{\text {th }}$ horizon was constructed (Fig. 3).

The associated base metal mineralization was mined in $18^{\text {th }}$ century; during the uranium exploration program, 


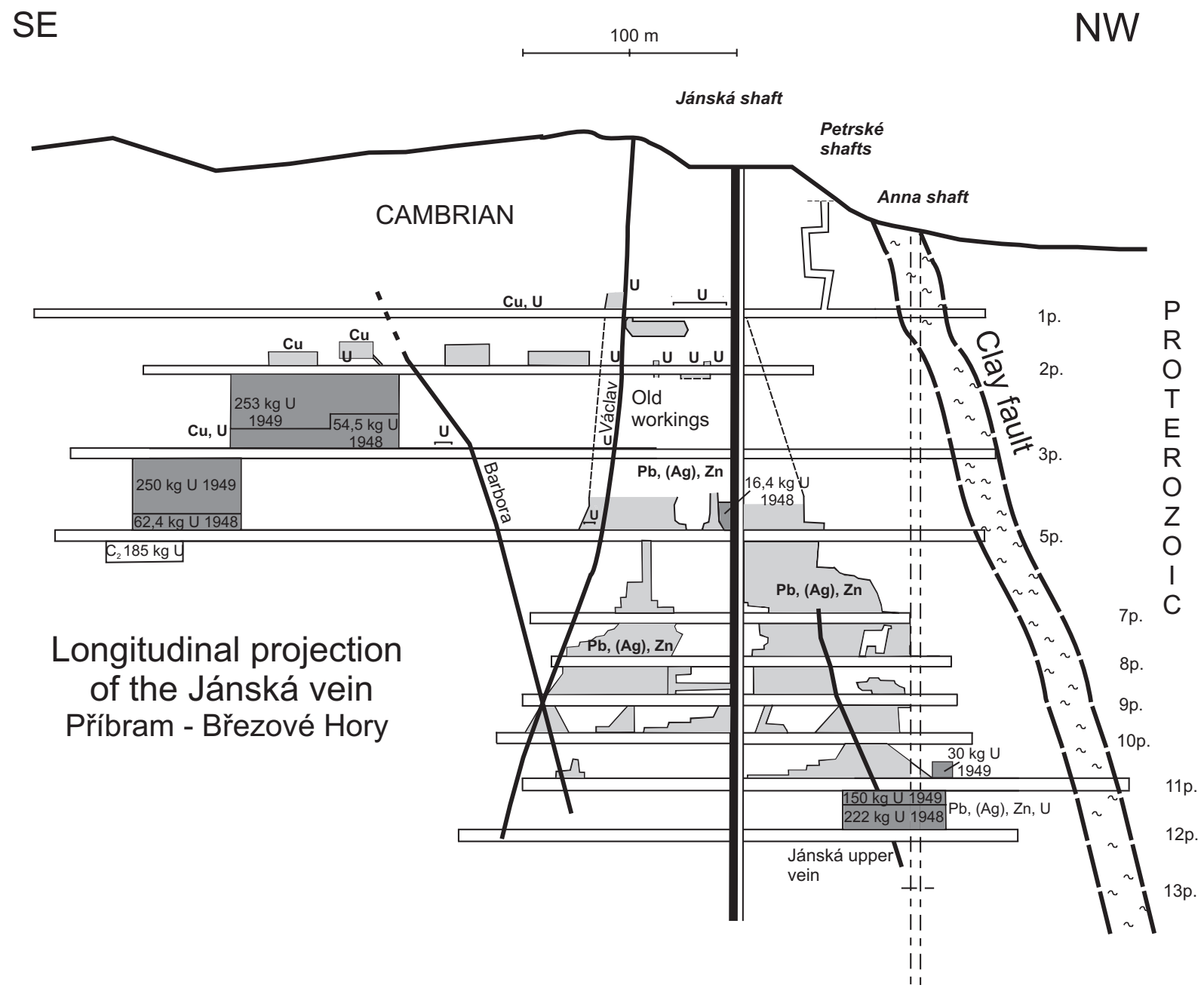

Fig. 3 Longitudinal vertical section of the works at Jánská vein. Original historic mining works for Ag-Pb are marked by light grey colour and stopes of uranium mining with mentioned quantity of the extracted metal from the years 1948-1949 are marked in dark grey.

some remaining ore accumulations and the stope between $11^{\text {th }}$ and $12^{\text {th }}$ levels were mined out. During years 1948 and 1949 , in total $1,038.3 \mathrm{~kg}$ of uranium was recovered (Author Collective 1949).

Several factors important in localization of uranium ores in the nearby Uranium district were observed. Most important were lithological, structural, and mineralogical factors. In the case of the Jánská vein structural predisposition predominates, as clearly seen in the northern ore pillar near the Jánská vein (Škácha 2007).

\subsection{Principal primary minerals of the Jánská vein}

Galena is the most abundant ore mineral. It forms large grains and fine-grained aggregates concentrated in several $\mathrm{cm}$ thick veinlets (Galena I). A younger galena generation
(Galena II) occurs together with uraninite and is often overgrown by anglesite in fractures. Although much of galena is older then uraninite, younger generation of the base metal mineralization in the Jánská vein contains uraninite with microscopic (probably syngenetic) inclusions of galena.

According to chemical analyses (Tab. 1) it is obvious, that galena I does not contain silver. Galena II is younger than sphalerite and coats its fragments. Both minerals are in close association with quartz according to the microscopic study (Fig. 4).

Uraninite is the dominant mineral of the uranium mineralization. It forms black fillings of veinlets up to $2 \mathrm{~cm}$ thick and kidney-shaped aggregates with a typical metallic lustre, on its own, or less commonly, in association with pyrite (Fig. 5). Larger homogeneous masses of uraninite show typical semi-metallic lustre and conchoi- 
Tab. 1 Electron-microprobe analyses of galena from the uranium mineralization (Galena I, sample 15J_1) in wt. \% and apfu

\begin{tabular}{lrr}
\hline & 1 & \multicolumn{1}{c}{2} \\
\hline $\mathrm{Pb}$ & 85.89 & 84.91 \\
$\mathrm{Ag}$ & $<0.01$ & $<0.01$ \\
$\mathrm{Sb}$ & 0.09 & $<0.01$ \\
$\mathrm{Bi}$ & $<0.01$ & 0.24 \\
$\mathrm{Te}$ & 0.10 & 0.03 \\
$\mathrm{Fe}$ & 0.04 & 0.02 \\
$\mathrm{~S}$ & 13.25 & 12.96 \\
$\mathrm{Cl}$ & 0.05 & 0.06 \\
\hline total & $\mathbf{9 9 . 4 1}$ & $\mathbf{9 8 . 2 1}$ \\
\hline $\mathrm{Fe}$ & 0.002 & 0.001 \\
$\mathrm{~Pb}$ & 0.997 & 1.003 \\
$\mathrm{Ag}$ & 0.000 & 0.000 \\
$\mathrm{Sb}$ & 0.002 & 0.000 \\
$\mathrm{Bi}$ & 0.000 & 0.003 \\
$\mathrm{Te}$ & 0.002 & 0.001 \\
$\mathrm{~S}$ & 0.994 & 0.989 \\
$\mathrm{Cl}$ & 0.003 & 0.004 \\
\hline
\end{tabular}

Sum of cations and anions $=2$ apfu

dal fracture. Weathered uraninite-bearing veinlets contain powdery uraninite aggregates. Some uraninite samples enclose galena. These samples come from an ore pillar in surroundings of the Jánská shaft. The genesis of this galena is probably related to remobilisation by younger uranium mineralization. Our microprobe study showed that this type of galena occurs in discrete zones of uraninite and individual galena grains are tiny, only several $\mu \mathrm{m}$ across (Fig. 6). Minor occurrences of uraninite from the southern ore pillar come from places where copper minerals surround uraninite and galena has not been de-

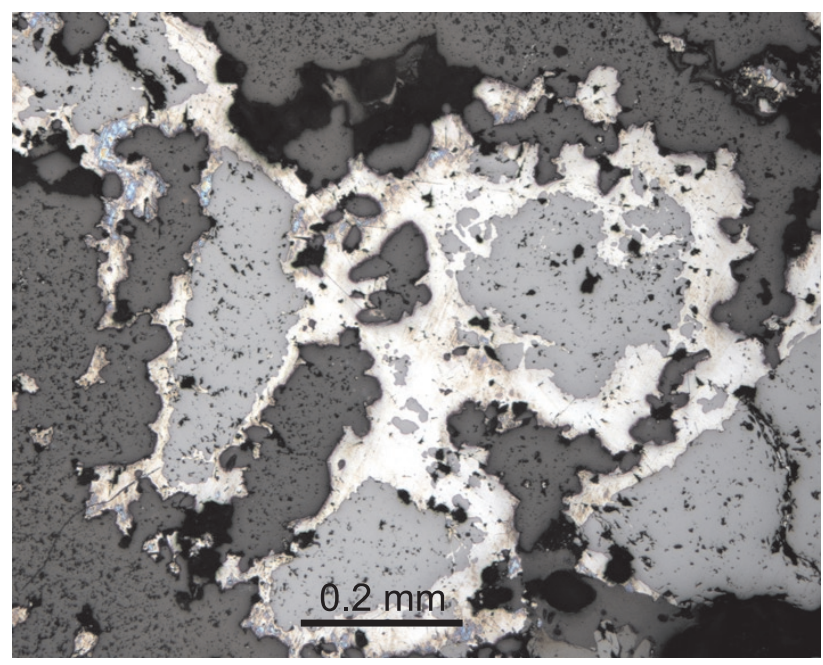

Fig. 4 Polished section from $2^{\text {nd }}$ level of the Jánská vein in reflected light. Light gray sphalerite is overgrown by white galena. Both phases are younger than dark gray quartz. Photo width $1 \mathrm{~mm}$. (photo by J. Sejkora and P. Škácha).

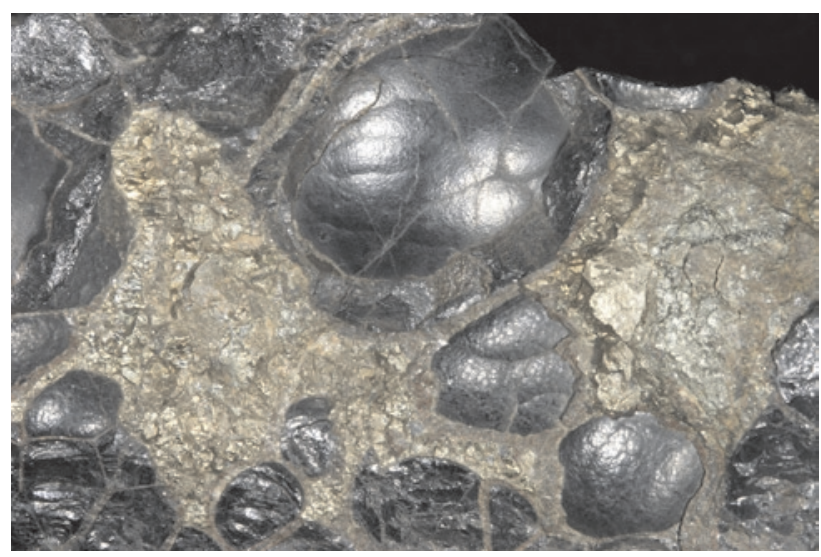

Fig. 5 Botryoidal uraninite ("pitchblende") aggregates up to $2 \mathrm{~cm}$ overgrown by younger pyrite from the $15^{\text {th }}$ level of the Jánská vein (collections of the Mining Museum in Př́bram, coll. No 853). Photo by P. Škácha.

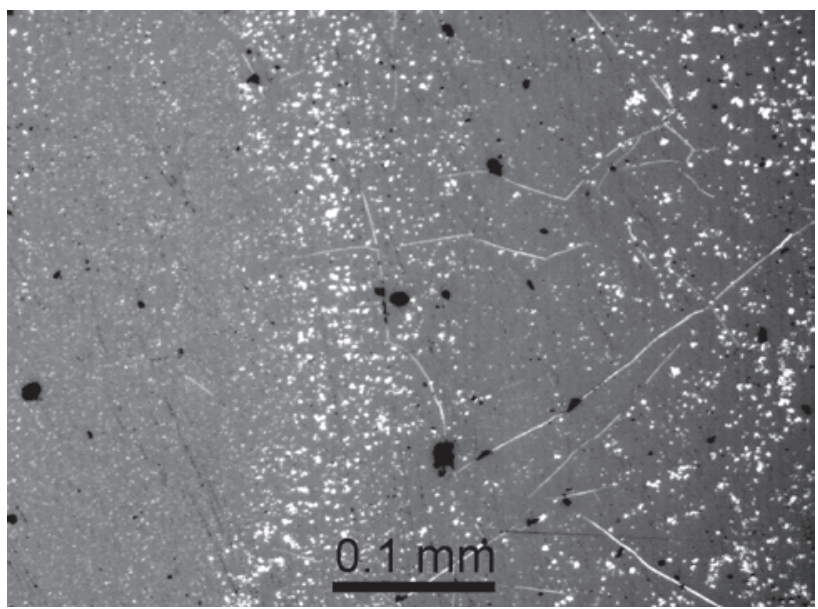

Fig. 6 BSE image of uraninite with light, finely disseminated grains and veinlets of non-radiogenic galena (sample J_1). Photo width $1.2 \mathrm{~mm}$. Photo by J. Sejkora and P. Škácha.

tected. This uraninite does not contain galena detectable by XRD, but ICP-MS established increased amounts of non-radiogenic $\mathrm{Pb}$. This indicates that the galena presence can be also expected at this locality.

Table 2 shows chemical composition of uraninite from the Jánská vein. The increased contents of $\mathrm{Ca}^{2+}$ can be according to Janezcek and Ewing (1992) explained by a $2 \mathrm{U}^{4+} \leftrightarrow \mathrm{U}^{6+}+\mathrm{Ca}^{2+}$ substitution. The other possibility is that the content of $\mathrm{Ca}$ is caused by submicroscopic carbonates inclusions, but it was not confirmed by the EMPA study. The content of $\mathrm{Pb}^{2+}$ corresponds to radiogenic $\mathrm{Pb}$ and, in part, to common lead in submicroscopic galena inclusions. Empirical formula of uraninite from the Jánská vein, based on 
Tab. 2 Electron-microprobe analyses of uraninite (in wt. \% and apfu)

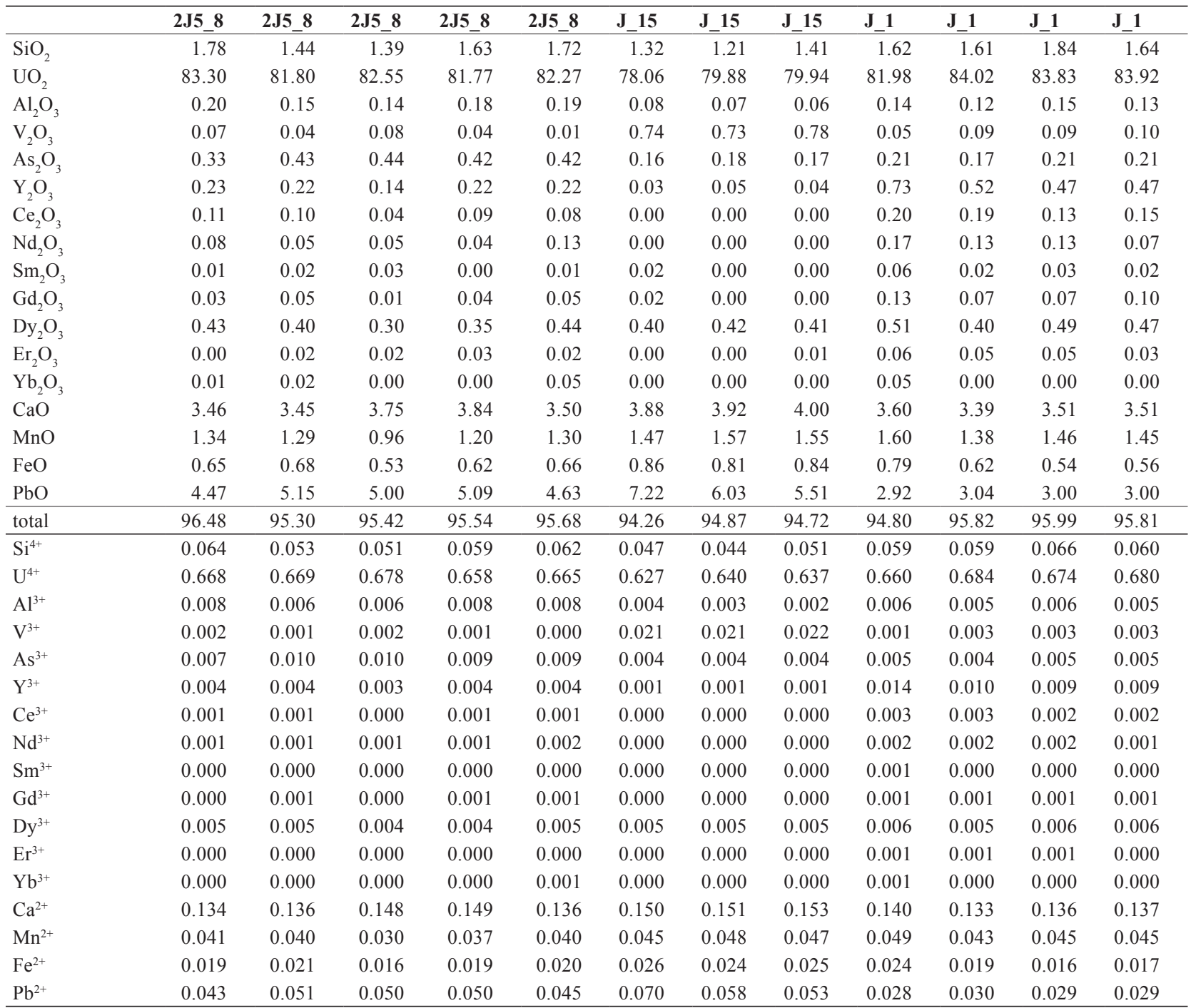

Sum of cations $=1$ apfu

Janeczek and Ewing (1992), is (mean of 12 analyses, based on sum of cations $+\mathrm{Si}=1$ apfu $)$ : $\left(\mathrm{U}_{0.66} \mathrm{REE}^{3+}{ }_{0.01}\right.$ $\left.\mathrm{M}^{3+}{ }_{0.02} \mathrm{M}^{2+}{ }_{0.25}\right)_{\Sigma 0.94}\left(\mathrm{SiO}_{4}\right)_{0.06} \mathrm{O}_{1.58}$.

According to Collective of Authors (1949) occurrences of uranium blacks ("sooty pitchblende") were recorded in the upper levels of the Jánská vein. We could verify this only in the southern ore pillar. After Jarka (2007) it contains 6.3 wt. \% U (alpha spectroscopy). The XRD study resulted in determination of an amorphous phase accompanied by chlorite.

Barite occurs frequently in the northern ore pillar as veinlets composed of tabular grains and as imperfect tabular crystals up to $1 \mathrm{~cm}$ in cavities. It is found in association with uraninite and base metal minerals at the $1^{\text {st }}$ and $2^{\text {nd }}$ levels. A younger barite generation occurs rarely with silver ores and uranium mineralization at the $2^{\text {nd }}$ level of the Prokop mine.

Calcite is a common mineral in the museum specimens from the Jánská vein. It forms massive aggregates of brown colour, often surrounding uraninite. It has not been found at presently accessible parts of the Jánská vein, except for rare recently-formed small crystals deposited on manganese oxides.

Quartz is the most common gangue mineral at the upper levels of the deposit. It forms mainly massive veinlet filling of grey or reddish colour and rare crystals to 1 $\mathrm{cm}$. In proximity to uranium minerals this quartz turns grey to black. 


\section{Lead isotopic composition of galena and uraninite}

The ${ }^{208} \mathrm{~Pb} /{ }^{206} \mathrm{~Pb}$ versus ${ }^{207} \mathrm{~Pb} /{ }^{206} \mathrm{~Pb}$ diagram (Fig. 7) was constructed from newly obtained data (Tab. 3). We added the following standard recommended values to the diagram: SRM 981 - Common Lead Isotopic Standard, SRM 982 - Equal Atom Lead Isotopic Standard, SRM 983 - Radiogenic Lead Isotopic Standard and measured values for Proterozoic uraninite standard CRM6-A ("Pitchblende ore").

The studied galena specimens from all of the Březové Hory ore deposits are isotopically homogeneous within analytical $2 \sigma$ errors (Fig. 7). Isotopic composition of uraninites from the Jánská vein varies within a broad range. Our data show that local uraninite contains a large amount of lead, which did not originate by U decay. On the contrary, the $\mathrm{Pb}$ isotopic composition of uraninites can be explained as mixture with syngenetic galena. This alternative is proved by the presence of minute galena inclusions in uraninite. From the compositions of the most likely end members, galena and theoretical uraninite end-member, we can calculate the amount of purely radiogenic lead (Tab. 3). In the studied set of uraninite samples the fraction of radiogenic lead varies from 48.0 to $89.8 \%$. This means that relatively small amount of non-radiogenic galena is sufficient for observed shifts in lead isotope compositions.

\section{1. ${ }^{207} \mathrm{~Pb} /{ }^{206} \mathrm{~Pb}$ lead isotope dating}

Due to the non-radiogenic lead admixture (contained in galena inclusions), the isotope analyses of uraninite form a linear array in Fig. 7. A pure uraninite has not been found, but its lead isotope composition could have been extrapolated by linear regression. One end member of this relation is formed by three points represented by galenas from the Jánská vein. These galenas are isotopically homogeneous within the measurement errors. Another end member (uraninite) was obtained at the intersection point of regression function with $\mathrm{x}$ axis $\left({ }^{208} \mathrm{~Pb} /{ }^{206} \mathrm{~Pb}=0\right)$ (Fig. 7).

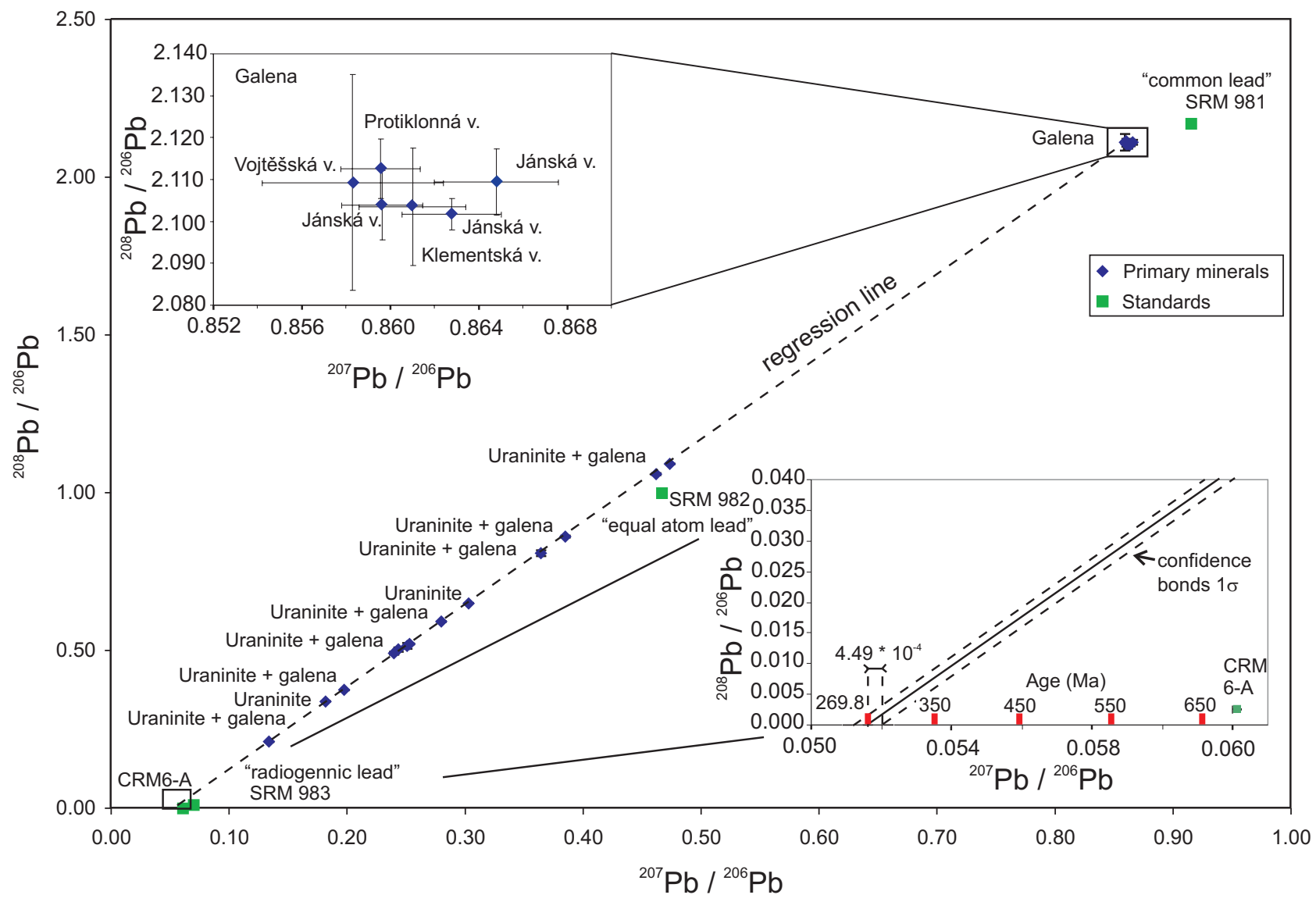

Fig. 7 Diagram ${ }^{208} \mathrm{~Pb} /{ }^{206} \mathrm{~Pb}$ versus ${ }^{207} \mathrm{~Pb} /{ }^{206} \mathrm{~Pb}$ for analyses of uraninite and galena from the Jánská vein with the position of theoretical radiogenic end-member (uraninite) and common lead end-member (galena). Linear fit to the data, enlarged area of the galena cluster, and intercept of the regression line with $\mathrm{x}$ axis (expressed also as time axis) are also shown. 


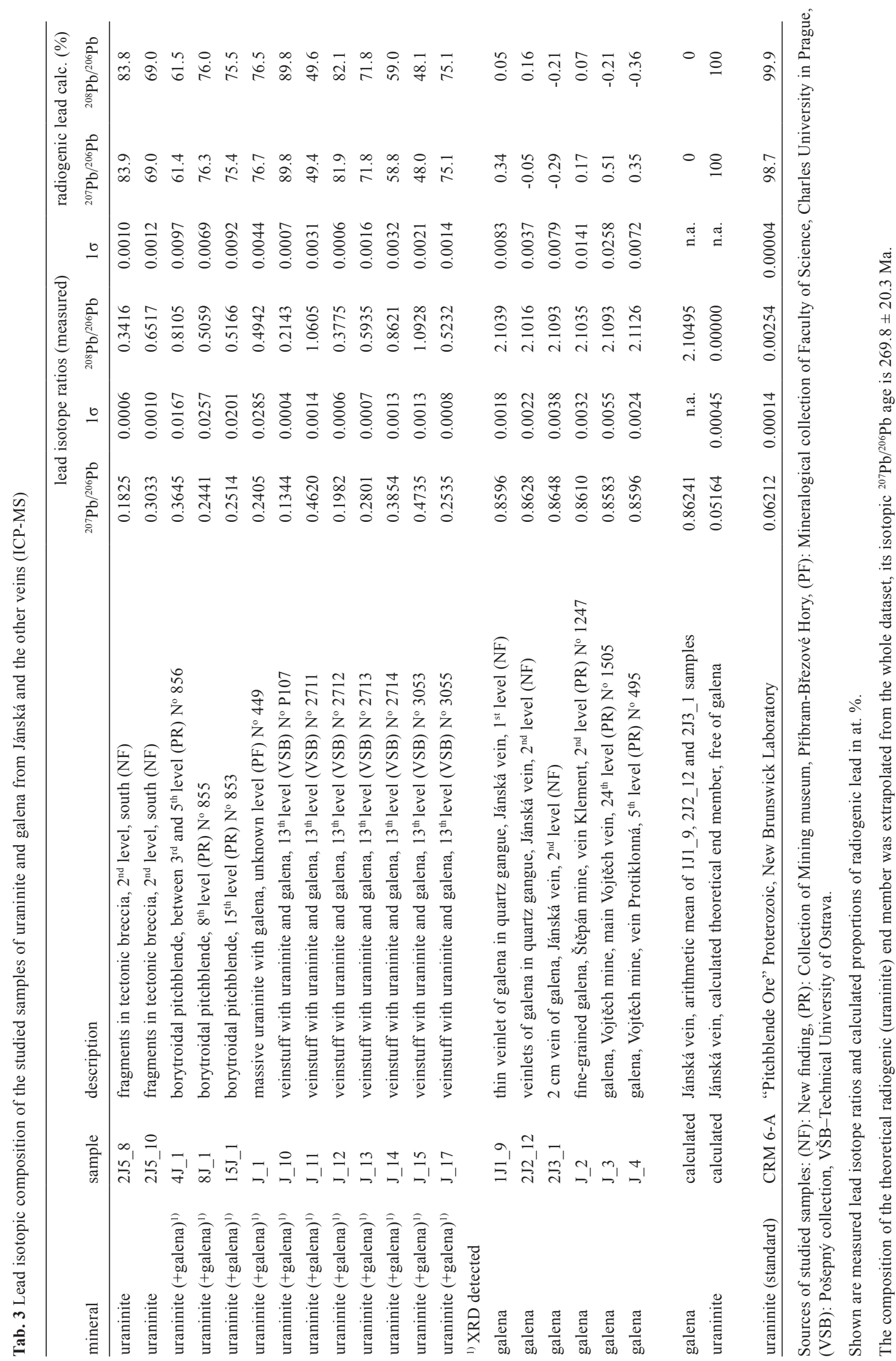


The age of the theoretical uraninite end member can be calculated following Faure (1986) as:

$$
\frac{{ }^{207} \mathrm{~Pb}}{{ }^{206} \mathrm{~Pb}}=\frac{1}{137.8} * \frac{e^{\lambda^{235} U^{*} t}-1}{e^{\lambda^{238} U^{*} t}-1}
$$

where the ratio ${ }^{207} \mathrm{~Pb} /{ }^{206} \mathrm{~Pb}$ corresponds to the $\mathrm{x}$-intercept of a straight line fitting data in Fig. $7, \lambda^{238}$ and $\lambda^{235}$ are decay constants for ${ }^{238} \mathrm{U}$ and ${ }^{235} \mathrm{U}$, respectively.

Using software NCSS we found the best-fit line to our data in the form ${ }^{208} \mathrm{~Pb} /{ }^{206} \mathrm{~Pb}=2.595147 *{ }^{207} \mathrm{~Pb} /{ }^{206} \mathrm{~Pb}-$ 0.134218 with standard error of the $\mathrm{y}$-intercept 0.000607 . The $\mathrm{x}$-intercept is calculated dividing the y-intercept by slope, yielding the theoretical pure uraninite end-member's ${ }^{207} \mathrm{~Pb} /{ }^{206} \mathrm{~Pb}=0.051719$. This corresponds to an age $270.7 \pm 26.9 \mathrm{Ma}$.

Nevertheless, such an approach does not take into account the errors of ${ }^{208} \mathrm{~Pb} /{ }^{206} \mathrm{~Pb}$ and ${ }^{207} \mathrm{~Pb} /{ }^{206} \mathrm{~Pb}$ ratios for individual data points. To solve this problem, we used a non-linear least squares inverse method of Tarantola and Valette (1982), which we implemented into Matlab software. The advantage of the method is that the equation (1) can be involved in the inversion as a constraining condition. The resulting age was similar to that obtained by the classical regression, but with a smaller error: 269.8 \pm 20.3 Ma.

\subsection{Chemical dating of uraninite}

On the basis of ICP-MS analyses, the chemical age of several uraninite specimens was determined. However, an unrealistically high lead amount was found in Variscan uraninites. In the light of isotopic data, microscopic and $\mathrm{X}$-ray diffraction study of the specimens, the increased content of lead is explained by the presence of galena inclusions of non-radiogenic origin (Fig. 6).

In a single case (sample $J_{-}$1), an inclusion-free area in polished section has been found (Tab. 2, anal. J_1-1 - J_1-4). But the influence of common lead in the bulk J_1 sample is evident (according to ICP-MS), like in the other uraninites (Tab. 3, anal. 2J5_8 and J_15). Consequently, an average chemical age for the inclusion-free area was calculated at $263.2 \pm 8.9 \mathrm{Ma}$ (uncertainty of age determination is expressed as $2 \sigma$, Tab. 4).

\section{Discussion}

The uranium mineralization occurrences on the Jánská vein are very interesting in respect to the evolution of the whole Březové Hory base metal deposit. According to known data and new observations, the Jánská vein filling resulted from a polyphase mineralization process.
A particularly intriguing question represents the genesis of galena inclusions present in all studied specimens of uraninite from the Jánská vein. Analogous type of galena, usually considered as being of radiogenic origin, was also found in other deposits worldwide, e. g. at Oklo deposit of Proterozoic age (Evins et al. 2005). Few uraninite grains with galena accounting for even up to $40 \mathrm{vol}$. \% were found in the Oklo deposit (Janezcek 1999). However, origin of the galena inclusions by $U$ decay was not confirmed by our ICP-MS data, which show that the galena inclusions have isotopic composition resembling the primary galena. The distribution of inclusions is uneven; their accumulations in certain zones of uraninite may suggest hydrothermal system pulsation. This galena could be related to a partial destruction of an older base metal mineralization by fluids associated with uranium mineralization. Non-radiogenic galena inclusions in uraninite are probably present in some other deposits, even though it cannot be proven without the isotope evidence (Löfvendhal and Åberg 1981). For instance, minute inclusions of remobilized $\mathrm{Pb}$ sulphoselenides were reported by Golubev et al. (2002) from outer zone of younger pitchblende at the Schlema-Alberoda deposit. Radiogenic origin of $\mathrm{Pb}$ was isotopically confirmed but no galena inclusions were mentioned by these authors.

Patočka et al. (1984) presented a review and re-interpretation of $\mathrm{Pb}$ isotope results from the $\mathrm{Czech}$ ore deposits measured by Legierski (1971, 1973), Bernard et al. (1979) and others. In this review were included two analyses of galena from Březové Hory and Bohutín. Our isotope data for galena from Jánská and other veins are very similar and illustrate homogenous source of non-radiogenic lead. On other hand our isotope and chemical age data $(269.8 \pm 20.3 \mathrm{Ma}$ and $263.2 \pm 8.9 \mathrm{Ma})$ for Březové Hory uraninite are very close or the same, within the error, compared to these previously published data for the nearby Príbram uranium ore district: $265 \pm$ $15 \mathrm{Ma}$ (Legierski 1973) or $275 \pm 4 \mathrm{Ma}$ to $278 \pm 4 \mathrm{Ma}$ (Anderson 1987).

The genesis of the Prríbram hydrothermal base metal and uranium deposits is spatially related to the exocontact of the Central Bohemian Plutonic Complex. The oldest recognized mineralization is quartz - Au-bearing, early Variscan stage, temporary related to the crystallization of the youngest phases of the plutonic complex. Some plutonic dykes are younger than the Au-bearing quartz veinlets as documented in Libčice near Nový Knín for instance by Slavík (1914) and Zoubek (1942). A newer dating was performed for early Variscan gold-bearing deposits (Zachariáš and Stein 2001): Petráčkova Hora (Re-Os molybdenite 342.1-348.5 Ma), Mokrsko (Re-Os molybdenite $342.9 \pm 1.4 \mathrm{Ma}$ ), Kasejovice (Re-Os molybdenite $338.5 \pm 1.3 \mathrm{Ma})$ and Jílové u Prahy $\left({ }^{40} \mathrm{Ar}-{ }^{39} \mathrm{Ar}\right.$ 
Tab 4 Chemical age of uraninite from the Jánská vein, calculated from EMPA analyses

\begin{tabular}{ll}
\hline & Chemical Age (Ma) \\
\hline sample J_1 & $262 \pm 15$ \\
& $265 \pm 15$ \\
& $263 \pm 15$ \\
& $263 \pm 15$
\end{tabular}

corrected (for Y and Th) average age $\quad 263.2 \pm 8.9$

standard age error is expressed as $2 \sigma$.

muscovite $338.6 \pm 0.5,339 \pm 0.6 \mathrm{Ma})$. It indicates that this mineralization stage overlapped, or followed shortly after, crystallization of the main granitoids in the Central Bohemian Plutonic Complex.

Base metal mineralization is younger than the quartz - gold-bearing mineralization. It can be deduced from the gangue relationships of a vein filling (e.g. in Bohutín deposit). There are numerous unpublished observations in this respect, kept in the Archive of DIAMO Enterprise; some of these data were summarized by Arapov et al. (1984). The U-Pb ages of 265-278 Ma (Legierski 1973) and $275 \pm 4$ to $278 \pm 4 \mathrm{Ma}$ (Anderson 1987) characterize the nearby uranium deposits. Similar ages were obtained by the K-Ar method for the Rožná uranium deposit in western Moravia: $277.2 \pm 5.5$ and $264 \pm 4.3 \mathrm{Ma}$ (Kříbek and Hájek 2005). Comparable data yielded samples from other deposits in the Bohemian Massif, including those in Germany (Golubev et al. 2002). Permian ages of the older uranium mineralization are typical of the French Massif Central as well as of the whole European Variscides (Marignac and Cuney 1999).

A younger mineralization process dated at $150-190$ Ma (Arapov 1984; Golubev et al. 2002; Kř́bek et al. 2003) seems important in relatively peripheral areas of the Bohemian Massif only (Krušné hory Mts., Bohemian Forest and Rožná-Olší deposits). Recrystallization and alteration of uraninite to coffinite is typical of this late process. This indicates a post-Variscan-early Alpine (Jurassic?) reactivation and rejuvenation of fault zones in the Bohemian Massif.

\section{Conclusions}

The uranium mineralization occurs in two ore pillars on the Jánská vein. Joint occurrence of base metal and uranium mineralizations is typical of the northern ore pillar. On the other hand, in the southern ore pillar uranium mineralization is associated with $\mathrm{Cu}$ mineralization. Uraninite is the dominant primary uranium phase on the
Jánská vein; base metal mineralization is represented by galena, sphalerite and pyrite. The most abundant gangue minerals are quartz, barite and minor calcite.

According to our isotopic data and microscopic study, uraninite always contains some proportion of non-radiogenic galena. It represents remobilized galena in the form of minute inclusions. The theoretical radiogenic (uraninite) end-member's $\mathrm{Pb}$ isotopic composition was extrapolated, corresponding to a ${ }^{207} \mathrm{~Pb} /{ }^{206} \mathrm{~Pb}$ age of 269.8 $\pm 20.3 \mathrm{Ma}$. In addition, it was possible to determine chemical age for one sample of uraninite $(263.2 \pm 8.9$ Ma). The data obtained by both methods are in a good agreement.

According to macroscopic and microscopic observations, base metal mineralization of the Jánská vein is older than the dated uranium mineralization. However, the field relations indicate relatively close genetic relations between the older base metal and the superimposed uranium mineralizations.

The age of uranium mineralization presented in this report is in good agreement with data published for other late Variscan hydrothermal uranium deposits.

Acknowledgments. The authors gratefully acknowledge cooperation of M. Fayadová, P. Jarka, J. Zachariáš and O. Šebek (Faculty of Science, Charles University in Prague, Prague), D. Ozdín (State Geological Institute of Dionýz Štúr, Bratislava), colleagues who kindly provided samples from museum collections, namely M. Duraj (VŠB - Technical University of Ostrava), P. Kašpar (Charles University in Prague), E. Litochlebová (Mining Museum, Prríbram) and of the DIAMO Enterprise, namely J. Kováŕ and K. Škvor, for support in course of this project. This work was financially supported by the Grant Agency of the Academy of Science ( $\mathrm{N}^{\circ}$ KJB - 301110602) and by Ministry of Education of the Czech Republic (MSM 0021620855).

\section{References}

ANDERSON EB (1987) Isotopic-geochronological investigation of the uranium deposits of Czechoslovakia. (MS) Czechoslovak Uranium Industry Report 1862-87, pp 1-32 (in Russian)

Arapov JA, Bojcov VJ, Č́esnokov Ni, Djakonov AV, Halbrštát J, Jakovjenko AM, Kolek M, Komínek J, Kozyrev VN, KRemČUKov GA, LažAnský M, MilovaNOv IA, NovÝ V, Šorf F (1984) Czechoslovak uranium deposits. ČSUP Př́ibram, pp 1-368 (in Czech)

Author Collective (1949) The Jáchymov mines enterprise calculation of resources for year 1948. Unpublished manuscript, DIAMO SUL, Příbram (in Russian) 
BABÁNEK F (1870) Die Gangverhältnisse der Anna-Neuprocopigrube am Birkenberge bei Przibram. Öster Zeitschrift f Berg u Hüttenwessen 18: 25-37

Bambas J (1990) The Březové Hory ore deposit. Př́íbram, pp 1-200 (in Czech)

Bernard J, Legierski J, Šmejkal V (1979) Isotopic investigation of ore paragenesis in the Bohemian Massif. Unpublished manuscript, Geofond, Prague, pp 1-87

Evins LZ, JENSEn KA, EwIng RC (2005) Uraninite recrystallization and $\mathrm{Pb}$ loss in the Oklo and Bangombé natural fission reactors, Gabon. Geochim Cosmochim Acta 69: 1589-1606

FAure G (1986) Principles of Isotope Geology. Second edition. John Willey \& Sons, New York, pp 1-589

Golubev VN, Chernyshev IV, Velichkin VI, Cuney M, Poty B. (2002) Isotopic constraints on the age at the Schlema-Alberoda uranium deposit (Erzgebirge). In: Kř́́BEK B, ZEMAN J (eds) Uranium deposits - From Their Genesis to Their Environmental Aspects. Czech Geological Survey, Prague, pp 57-60

Grimm J (1856) Die Erzniederlage bei Přibram in Böhmen. Berg Hüttenm Jahrb 5: 93-168

HinTZE J (2001) NCSS and PASS. Number Cruncher Statistical Systems. Kaysville, Utah, http:/www.ncss.com/

Holub FV, Cocherie A, Rossi P (1997) Radiometric dating of granitic rocks from the Central Bohemian Plutonic Complex (Czech Republic): constrains on the chronology of thermal and tectonic events along the MoldanubianBarrandian boundary. C R Acad Sci IIA 325: 19-26

ICDD (2003) PDF-2 database, ICDD, Newton Square, PA, USA

JANECZEK J, EwING RC (1992) Structural formula of uraninite. J Nucl Mater 190: 128-132

JANECZEK J (1999) Mineralogy and geochemistry of natural fission reactors in Gabon. In: BuRns PC, FINCH R (eds) Uranium: Mineralogy, Geochemistry and the Environment. Mineralogical Society of America Reviews in Mineralogy 38: pp 321-392

JANOUŠEK V, Braithwaite CJR, Bowes DR, Gerdes A (2004) Magma-mixing in the genesis of Hercynian calc-alkaline granitoids: an integrated petrographic and geochemical study of the Sázava intrusion, Central Bohemian Pluton, Czech Republic. Lithos 78: 67-99

JARKA P (2007) Uranium-base metal mineralization of the Jánská vein, Příbram-Březové Hory, Czech Republic: alpha spectrometric determination of the radionuclides. Unpublished MSc. thesis. Faculty of Science, Charles University in Prague, pp 1-45 (in Czech)

KirChHEIMER F (1963) Uran und seine geschichte. E. Schweizerbartsche Verlagsbuchhandlung, Stuttgart, pp 1-372

KŘíbek B, Žák K, Spangenberg J, JehličKa J, Prokeš S, KomíneK J (2003) Bitumens in the late Variscan hydro- thermal vein-type uranium deposit of Př́bram, Czech Republic: sources, radiation-induced alteration, and relation to mineralization. Econ Geol 94: 1093-1114

Ǩ̌íBeK B, HÁseK A, (eds) (2005) Rožná uranium deposit: model of late Variscan and post Variscan mineralizations. Czech Geological Survey, Prague, pp 1-98 (in Czech)

Legierski J (1971) Pb-Pb, U-Pb, U-Th- $\mathrm{Pb}$ methods and their application on the ore deposits. Unpublished PhD. thesis, Faculty of Science, Charles University in Prague, pp 1-145 (in Czech)

LEGIERSKI J (1973) Model ages and isotopic composition of ore leads of the Bohemian massif. Čas Min Geol 18: 1-23 (in Czech)

LÖFVENDHAL R, ÅBERG G (1981) An isotope study of Swedish secondary U-Pb minerals. Geol Fören i Stockholm Förhand 103: 331-342

Marignac C, Cuney M (1999) Ore deposits of the French Massif Central: insight into the metallogenesis of the Variscan collision belt. Miner Depos 34: 472-504

Mihaljevič M, Zuna M, Ettler V, Šebek O, Strnad L, GoLIÁŠ V (2006) Lead fluxes, isotopic and concentration profiles in a peat deposit near a lead smelter (Př́bram, Czech Republic). Sci Total Environ 372: 334-344

Montel JM, Foret S, Veschambre M, Nicollet C, Provost A (1996) Electron microprobe dating of monazite. Chem Geol 131: 37-53

PatočKa F, Pošmourný K, Rajlich P, Richter A, VAnĚček $\mathrm{M}$ (1984) $\mathrm{Pb}$ isotopic data utilization for prospection in volcanosedimentary areas of the Bohemian Massif. Czech Geological Survey, Prague, pp 1-84 (in Czech)

Pouchou JL, Pichoir F (1985) "PAP" procedure for improved quantitative microanalysis. Microbeam Anal 20: 104-105

Schmidt J (1892) Montan-geologische Beschreibung des Příbramer Bergbau - Terrains und der Verhältnisse in der Grube. K.k. Hof und Stadtdruckerei, Wien, pp 1-62

SLAvík F (1914) Die Goldquartzgänge Mittelböhmens. Z prakt Geol Lagerstättenkde 22: 343-373

Strnad L, Mihaljevič M, ŠEBeK O (2005) Laser ablation and solution ICP-MS determination of REE in USGS BIR$1 \mathrm{G}, \mathrm{BHVO}-2 \mathrm{G}$ and BCR-2G glass reference materials. Geostand Geoanal Res 29: 303-314

ŠKÁCHA P (2007) Characterization of the uranium-polymetallic mineralization of the Jánská vein and redistribution of lead isotopes into the secondary phases, Příbram-Březové Hory, Czech Republic. Unpublished MSc. thesis. Faculty of Science, Charles University in Prague, pp 1-41 (in Czech)

Tarantola A, Valette B (1982) Generalized nonlinear inverse problems solved using the least squares criterion. Rev Geophys Space Phys 20: 219-232

Zachariáš J, Stein H (2001) Re-Os ages of Variscan hydrothermal gold mineralisations, Central Bohemian 
metallogenetic zone, Czech Republic. In: PIESTRZYŃsKi ET AL. (eds): Mineral Deposits at the Beginning of the $21^{\text {st }}$ Century, Swets \& Zeitlinger Publishers, Lisse, pp 851-854

Zоuвeк V (1942) Geologisches Gutachten über das Liebschitzer-Borotitzer goldführende Gebiet. Unpublished manuscript, Geofond, Prague pp 1-15
ŽÁA K, Doвeš P (1991) Stable isotopes and fluid inclusions in hydrothermal deposits: the Př́bram ore region. Rozpr ČSAV: $1-109$

ŽÁk K, Vlašímský P, Lawrence W. Snee (1998) ${ }^{40} \mathrm{Ar} /{ }^{39} \mathrm{Ar}$ cooling ages of selected rocks of the Príbram ore region and the question of timing of sulfidic hydrothermal mineralization. Zpr geol výzk za Rok 1997, pp 172-173 (in Czech)

\section{Hydrotermální uran-polymetalická mineralizace Jánské žíly, Březové Hory, Příbram, ČR: izotopy $\mathrm{Pb}$ a chemické datování uraninitu}

Jánská žíla je jednou z významných žil březohorského ložiska. Od 14. stol. zde byly dobývány polymetalické rudy a krátce také na konci 50 . let 20. stol. i rudy uranové. V rámci předkládané práce byl studován především archivní vzorkový materiál. Uranová mineralizace je mladší než větší část mineralizace polymetalické, což bylo prokázáno jak makrostrukturním, tak i mikroskopickým studiem. Většina vzorků uraninitu obsahuje více či méně galenitových inkluzí. Tento galenit je podle výsledků ICP-MS analýz neradiogenní. Jeho vznik je pravděpodobně spojen s remobilizací galenitu mladší uranovou mineralizací. Koncentrace radiogenního olova v uraninitu kolísají od 48,0 do 89,8 rel. \%. Stáří teoretického krajního členu uraninitu, které bylo statisticky spočítáno z celého souboru naměřených dat (pro průsečík ${ }^{208} \mathrm{~Pb} /{ }^{206} \mathrm{~Pb}=0$ ), činí 269,8 $\pm 20,3 \mathrm{Ma}$. Bylo nalezeno jediné zrno uraninitu lokálně bez inkluzí galenitu, které bylo použito pro datování pomocí vlnově-disperzní elektronové mikroanalýzy. Získané chemické stáří uranové mineralizace, 263,2 \pm 8,9 Ma, dobře odpovídá publikovaným údajům pro ostatní hydrotermální uranová ložiska Českého masívu. 